\title{
PRINSIP-PRINSIP GOOD GOVERNANCE PADA PENGELOLAAN ZAKAT DALAM PERSPEKTIF QARDHAWI: Studi pada Baitul Mal Kabupaten Aceh Tengah
}

\author{
Iwan Fitrah, Iwan Triyuwono, Noval Adib \\ Fakultas Ekonomi dan Bisnis - Universitas Brawijaya Malang \\ bang.one_fitrah@yahoo.co.id
}

Abstract

The existence of various problems in the implementation of zakat management in the zakat organizations originated from the problem concerning some things called the principles of good governance. So to overcome the problems is by strengthening those principles. This study aims to describe the principles of good governance in the zakat management of Baitul Mal Central Aceh District on Qardhawi perspective. The analysis method used is descriptive-qualitative, with case study research strategy. Data collected through interviews, observation, and documentation. The results show that the principles of shariah, trust, equity, and participation have been going well, but the shariah principle implementation becomes constrained when facing the mechanism of zakat as Regional Original Revenue. Principles of accountability and transparancy have been implemented, but still do not use a more adequate system. Furthermore, the zakat management is still inefficient because amilfunds still exceed the provisions, and also there is no amil standarization regarding the relevant educational background with zakat to support the zakat management professionally.

Adanya berbagai persoalan dalam pelaksanaan pengelolaan zakat pada organisasi pengelola zakat berakar dari masalah menyangkut beberapa hal yang dikenal dengan prinsip-prinsip good governance. Sehingga untuk mengatasipersoalan dimaksud adalah dengan melakukan penguatan pada prinsip-prinsip tersebut. Penelitian ini bertujuan untuk menggambarkan prinsip-prinsip good governance dalam pengelolaan zakatpada Baitul Mal Kabupaten Aceh Tengah ditinjau melalui perspektifQardhawi. Metode analisis yang digunakan adalah deskriptif-kualitatif, dengan strategi penelitian studi kasus. Pengumpulan data melalui wawancara, observasi, dan dokumentasi. Hasil 
penelitian menunjukan bahwa prinsip syariah, amanah, keadilan, dan partisipasi telab berjalan dengan baik, namun pelaksanaan prinsip syariah menjadi terkendala ketika dihadapkan pada mekanisme zakat sebagai Pendapatan Asli Daerah. Prinsip akuntabilitas dan transparansi telah dilaksanakan, namun sistem yang lebih memadai masih belum digunakan. Selanjutnya, pengelolaan zakat masih kurang efisien karena dana amil masih melebibi ketentuannya, dan tidak adanya standarisasi bagi amil mengenai latar belakang pendidikan yang relevan dengan zakat untuk mendukung pengelolaan zakat secara profesional.

Keywords: Good governance, Qardhawi, Zakat, Baitul Mal

\section{Pendahuluan}

Secara ekonomi, zakat memiliki manfaat yang besar untuk membantu dan membina para penerima zakat (mustahiq) mengarah pada penghidupan yang lebih baik. Dalam Islam ditekankan adanya suatu distribusi atas harta dan pendapatan yang diperoleh sebagaimana QS Al-Hasyr: 7. Salah satu cara yang dianut dalam syariah atas kewajiban kolektif perekonomian umat Islam adalah melalui lembaga zakat. ${ }^{1}$ Zakat sebaiknya dipungut oleh Negara, agar fakir miskin memperoleh haknya yang terdapat pada orang-orang kaya. ${ }^{2}$ Zakat bukan hanya urusan yang dilaksanakan atas kesadaran pembayar zakat (muzaki) semata, tetapi pada Negara dengan mengangkat orang yang memenuhi syarat sebagai amil. ${ }^{3}$ Sebagaimana perintah dalam QS At-Taubah: 60 untuk mengalokasikan zakat kepada golongan yang berhak menerimanya melalui petugas yang ditunjuk (amil). Reorganisasi zakat begitu penting mengingat kenyataan dalam sejarah masa lalu yang sukses dalam mengantisipasi kemiskinan umat. ${ }^{4}$ Oleh karena itu, lembaga zakat memiliki peran penting bagi kelangsungan zakat dalam rangka mengelola dana untuk umat.

Saat ini, pengelolaan zakat di berbagai Organisasi Pengelola Zakat sudah terlaksana sedemikian rupa. Namun, masih ditemukan beberapa isu dalam pengelolaannya. Sebagian permasalahan zakat di Indonesia disinyalir akibat dari lemahnya aspek pengelolaannya. Pola pengelolaan (tata kelola) zakat klasik seyogianya sudah dapat bergeser pada upaya tata kelola pendekatan konsep good governance zakat. ${ }^{5}$ Muzaki menginginkan pengelolaan dan pendayagunaan zakat 1 Merza Gamal, Aktifitas Ekonomi Syariah (Catatan Dakwah Seorang Praktisi Perbankan Syariah) (Pekanbaru: Unri Press, 2004), h. 81

2 Mohammad Daud Ali, Sistem Ekonomi Islam: Zakat dan Wakaf(Jakarta: UI-Press, 1988), h. 5

3 Didin Hafidhuddin, Panduan Praktis tentang ZIS (Jakarta: Gema Insani Press, 1998), h. 19

4 Muhammad \& Abubakar. Manajemen Organisasi Zakat: PerspektifPemberdayaan Umat dan Pengembangan Organisasi Pengelola Zakat (Malang: Madani-Kel. Penerbit Intrans, 2011), h. 17

5 Ahmad Fadli, Good Governance Zakat di Indonesia. Al-Iqtishadi. Vol. 2 No. 1: 2015, h. 84 
yang lebih baik, di antaranya pengelolaan zakat secara profesional, transparansi, dan penyaluran yang tepat pada sasarannya. ${ }^{6}$ Transparansi dalam pengelolaan zakat sangat dibutuhkan di era kontemporer, karena umumnya kepercayaan muzaki akan meningkat tatkala dibuktikan dengan realitas terlebih dahulu. ${ }^{7}$ Dengan demikian, faktor kepercayaan merupakan hal yang sangat perlu diperhatikan. Apabila kualitas transparansi informasi, akuntabilitas, dan kemanfaatan dana zakat dapat ditingkatkan dengan baik, maka dapat memberikan dampak yang sangat positif terhadap kepuasan muzaki. ${ }^{8}$ Akuntabilitas umumnya diwujudkan dalam bentuk laporan. Namun, akuntabilitas lembaga syariah memiliki bentuk akuntabilitas yang kompleks. Akuntabilitas tidak hanya kepada stockholders, tetapi juga akuntabilitas kepada pihak lain yang turut berkepentingan serta kepada Tuhan. ${ }^{9}$ Dalam pengelolaan zakat juga diperlukan partisipasi dari berbagai pihak di luar lembaga zakat, misalnya dalam hal evaluasi. Adanya keterlibatan muzaki dalam evaluasi kinerja lembaga pengelola zakat setiap akhir periodenya akan memberikan kepuasan terhadap muzaki. ${ }^{10}$ Kemudian, diperlukan standar tata kelola yang baik pada lembaga zakat, di mana salah satu indikatornya yakni efisiensi sebagai tolak ukur kinerja lembaga keuangan. ${ }^{11}$ Masalah lainnya dalam pengelolaan zakat ialah terdapatnya penyimpangan yang dilarang dalam Islam. Di antaranya, zakat beserta instrumen Islam lainnya seperti infak/shadaqah, semestinya memiliki tujuan yang searah dengan perspektif ekonomi Islam, namun penyimpangan dalam implementasinya masih banyak. ${ }^{12}$

Berdasarkan beberapa penyebab persoalan pada pengelolaan zakat yang telah dipaparkan, ditemukan hal-hal yang umumnya dihadapai oleh lembaga zakat berakar dari beberapa hal seperti akuntabilitas, transparansi, profesionalitas, efisiensi, partisipasi. amanah, dan kemanfaatan. Diketahui bahwa, hal-hal tersebut

6 Yosi Dian Endahwati, Akuntabilitas Pengelolaan ZIS.JINAH. Vol. 4, No. 1: 2014, hal. 139

7 Ahmad Atabik, Manajemen Pengelolaan Zakat yang Efektif di Era Kontemporer. ZISWAF. Vol. 2, No. 1:2015, h. 56

8 Jumaizi\&Zainal A Wijaya, Good Governance BAZIS dan Dampaknya Terhadap Keputusan dan Loyalitas Muzaki. Majalah Ilmiah Informatika. Vol. 2 No. 3: 2011, h. 36

9 Iwan Triyuwono, Sinergi Oposisi Biner: Formulasi Tujuan Dasar Laporan Keuangan Akuntansi Syari'ah. IQTISAD-Journal of Islamic Economics. Vol. 4, No. 1: 2003, h. 84

10 H.S. Kuncaraningsih \& M. Rasyid Ridla, Good Corporate Governance Dalam Meningkatkan Kepuasan Muzakki di Badan Amil Zakat Nasional. Jurnal MD. Edisi Januari-Juni, 2015, h. 99

11 Kadry, R. Analisis Efsiensi Lembaga Amil Zakat (LAZ) di Indonesia. (Studi Kasus Pada Rumah Zakat, LAZIS Swa-daya Ummah, Dompet Dhuafa dan YBUI-BNI Tahun 20102012). Tesis tidak diterbitkan. (Yogyakarta: UIN Sunan Kalijaga, 2014), h. 6

12 Any Setianingrum, Desentralisasi Fiskal Kontemporer Dalam Perspektif Kebijakan Publik Islam. Ekonomika-Bisnis. Vol. 4 No.1: 2013, h. 11 
merupakan unsur-unsur yang umum melekat dalam tata kelola yang dikenal dengan prinsip-prinsip good governance. Sehingga untuk mengatasi permasalahan lembaga pengelola zakat, maka diperlukan adanya penguatan lembaga dalam pengelolaannya (tata kelolanya). Penguatan tata kelola zakat dapat diwujudkan dengan optimalisasi pada prinsip-prinsip seperti tersebut. Di samping itu, pengelolaan zakat tidak terlepas dari ketentuan yang berlandaskan syariah dalam konteks zakat. Berikut beberapa di antara penelitian mengenai penguatan good governance yang diwujudkan melalui prinsipnya:

Kajian mengenai penguatan good governance yang diwujudkan melalui prinsipnya pernah dilakukan oleh Nikmatuniayah \& Marliyati mengenai akuntabilitas laporan keuangan pada enam Lembaga Amil Zakat (LAZ) dan satu Baznas di Kota Semarang. Yang mengungkapkan bahwa akuntabilitas atau pertanggungjawaban LAZ ditujukan kepada para pemangku kepentingan ZIS yakni kepada masyarakat (muzaki), Negara (pemerintah) dan tentunya pertanggungjawaban tertinggi kepada Allah SWT. Pertanggungjawaban objek penelitian yang diwujudkan melalui laporan keuangan yakni meliputi neraca, laporan arus kas, dan laporan perubahan dana pada umumnya dilaksanakan dengan baik. Sementara untuk laporan aset kelolaan belum semuanya melaksanakan. Kajian berikutnya adalah dilakukan oleh Lestari, dkk. Yang menjelaskan mengenai penguatan tata kelola dalam rangka e-Governance pada sembilan organisasi pengelola zakat (OPZ) di Kabupaten Banyumas. Hasilnya menunjukan bahwa hanya sebesar 11,11\% OPZ yang memanfaatkan website sebagai media informasi kepada masyarakat. Hal itu menyebabkan terbatasnya akses informasi masyarakat atas pengelolaan zakat dan sosialisasi program. Oleh karena itu, perlunya penggunaan teknologi informasi oleh OPZ guna meningkatkan transparansi.

Kajian good governance juga dilakukan oleh Utamy yaitu mengenai keadilan ekonomi dalam pendistribusian zakat pada Baznas Tanah Datar(BTD), dinyatakan bahwa pendistribusian zakat oleh BTD seharusnya memberikan keadilan. Hal ini dikarenakan strategi pendistribusian BTD melalui penetapan kuota dana zakat ke setiap kecamatan berdasarkan besaran zakat yang masuk dari masing-masing kecamatan tersebut. Implikasinya adalah problem pemerataan, yakni kecamatan dengan setoran zakat sedikit akan memperoleh kuota sedikit, sebaliknya kecamatan yang setorannya banyak maka kuotanya semakin banyak. Semestinya, di samping menggunakan strategi seperti tersebut di atas, hendaknya diimbangi dengan penambahan alokasi untuk daerah yang penyetoran zakatnya kecil, misalnya penambahan berasal dari penerimaan zakat dari tingkat kabupaten. 
Kajian berikutnya adalah oleh Setiadi \& Hambali yang membahas mengenai peran amil zakat dalam mengoptimalkan zakat produktif pada Bazda Kota Bekasi (BKB). Dalam hasil peneltiannya disebutkan bahwa sebelum pelaksanaan pendistribusiann zakat pada BKB, maka dilakukan musyawarah terlebih dahulu dalam rangka analisa distribusi zakat. Musyawarah dilakukan dengan harapan agar hasil dari (keputusan) musyawarah dapat mempengaruhi kesejahteraan muzaki menjadi lebih baik. Musyawarah tersebut dengan melibatkan partisipasi dari seluruh pengurus. Mursal juga menjelaskan terkait profesionalisme, bahwa terdapat kelemahan pada SDM Bazda Kabupaten Kerinci. Kelemahan tersebut terkait kompetensi pengetahuan terutama menyangkut teoritis fikih zakat. Selain itu juga menyangkut pengetahuan manajemen zakat, akuntansi keuangan, ekonomi Islam, serta kemampuan teknis dalam operasional dan pengalaman yang belum luas. Oleh karena itu diperlukan kompetensi SDM amil yang memadai, terutama dalam hal pengetahuan hukum atau fiqih zakat.

Kajian lembaga amil zakat oleh Haq \& Djayusman juga menjelaskan efisiensi Lembaga Amil Zakat Umat Sejahtera Ponorogo (LAZ USP) dengan indikator yang digunakan adalah penggunaan biaya personalia (amil), biaya sosialisasi, dan biaya operasional. Hasilnya menunjukan bahwa semakin tinggi penggunaaan biaya personalia (amil), biaya sosialisasi, dan biaya operasional maka tingkat efisiensi akan menjadi semakin menurun, dan sebalinya. Oleh karena itu, untuk mencapai tujuan utama zakat dalam menyelesaikan problematika kemiskinan maka perlu menjaga efisiensi atas biaya-biaya tersebut.

Dengan melihat beberapa penelitian sebagaimana tersebut di atas, pada suatu organisasi non profit dalam berbagai bidang termasuk bidang sosial keagamaan seperti halnya lembaga zakat, harus menyadari betapa pentingnya prinsip-prinsip good governance dengan tetap memperhatikan karakteristiknya sebagai lembaga bermuatan syariah. Salah satu lembaga zakat yang urgen untuk melaksanakan penguatan prinsip-prinsip good governance adalah Baitul Mal Kabupaten Aceh Tengah (selanjutnya BMK). Baitul Mal di Aceh (termasuk BMK) adalah suatu lembaga zakat yang memiliki kompleksitas dalam pengelolannya. Selain mengelola zakat, BMK juga mengelola harta lainnya, termasuk juga wakaf beserta kewenangan lain. ${ }^{13}$ Selain itu, penerimaan zakat di Aceh dianggap sebagai PAD (Pendapatan Asli Daerah). ${ }^{14}$ Dengan kompleksitas tersebut, menuntut pengelolaan lebih optimal

13 Pasal 8 pada Qanun Aceh No. 10 Tahun 2007 tentang Baitul Mal

14 Pasal 4 ayat (2) Huruf c pada Undang-Undang No. 18 Tahun 2001 tentang Otonomi Khusus bagi Provinsi Daerah Istimewa Aceh Sebagai Provinsi Nanggroe Aceh Darussalam; Kemudian pada pasal 18 ayat (1) huruf d dan Pasal 191 dalam Undang-Undang No. 11 Tahun 2006 tentang Undang-Undang Pemerintahan Aceh 
dan tetap mengedepankan ketentuan syariah.

Tabel 1. Penerimaan Zakat dan HA pada Baitul Mal Seluruh Aceh

\begin{tabular}{llllll}
\hline \multirow{2}{*}{ No } & \multirow{2}{*}{ Kab./Kota } & \multicolumn{4}{c}{ TAHUN } \\
\cline { 3 - 6 } 1 & 2012 & 2013 & 2014 & 2015 \\
\hline 2 & Simeulu & 1.612 & 1.202 & 3.455 & 3.452 \\
\hline 3 & Aceh Singkil & 1.313 & 1.563 & 1.846 & 2.200 \\
\hline 4 & Aceh Selatan & 1.871 & 1.968 & 4.218 & 6.035 \\
\hline 5 & Aceh Tenggara & 1.897 & 3.733 & 4.348 & 4.960 \\
\hline 6 & Aceh Tengah & 3.857 & 3.703 & 6.484 & 3.549 \\
\hline 7 & Aceh Barat & 4.910 & 8.146 & 13.815 & 16.113 \\
\hline 8 & Aceh Besar & 11.659 & 11.819 & 10.140 & 11.122 \\
\hline 9 & Aceh Pidie & 2.071 & 3.190 & 14.815 & 15.838 \\
\hline 10 & Bireuen & 3.194 & 4.712 & 6.340 & 3.429 \\
\hline 11 & Aceh Utara & 15.582 & 11.401 & 8.783 & 21.413 \\
\hline 12 & Aceh Barat daya & 1.792 & 1.899 & 1.818 & 2.921 \\
\hline 13 & Gayo Lues & 1.435 & 1.641 & 2.080 & 4.114 \\
\hline 14 & Aceh Tamiang & 1.293 & 2.163 & 3.670 & 8.966 \\
\hline 15 & Nagan Raya & 3.516 & 3.516 & 4.006 & 4.023 \\
\hline 16 & Aceh Jaya & 1.200 & 2.324 & 3.411 & 4.624 \\
\hline 17 & Bener Meriah & 3.668 & 5.347 & 6.933 & 9.380 \\
\hline 18 & Pidie Jaya & 2.428 & 2.235 & 2.501 & 3.182 \\
\hline 19 & Banda Aceh & 19.627 & 14.500 & 15.736 & 17.634 \\
\hline 20 & Sabang & 2.734 & 3.492 & 4.219 & 4.544 \\
\hline 21 & Langsa & 2.244 & 2.395 & 4.543 & 3.680 \\
\hline 22 & Lhoksemawe & 2.009 & 1.405 & 6.141 & 7.621 \\
\hline 23 & Subusalam & 1.394 & 1.446 & 1.977 & 3.555 \\
\hline
\end{tabular}

Sumber: Dokumen "Aceh dalam Angka",

Tahun 2012, 2013, 2014, dan 2015

Kemudian, BMK adalah salah satu dari 23 Kabupaten/Kota yang memiliki penerimaan zakat dan HA (Harta Agama) dalam kategori tinggi di lingkup Aceh. Penerimaan BMK dari tahun 2012 hingga 2015 sebagaimana pada tabel 1. Sementara rata-rata penerimaan seluruh Aceh dari tahun 2012 hingga 2015 adalah Rp. 4,270 miliar, Rp. 4,421 miliar, Rp. 5,828 miliar, dan Rp. 7,374 miliar. Berdasarkan data tersebut, penerimaan BMK pada setiap tahunnya lebih besar dari rata-rata penerimaan seluruh Aceh. Sebagai salah satu lembaga zakat yang memiliki penerimaan besar, menuntut amil atau lembaga zakat agar lebih berhati-hati dalam menjaga dan mengelola dana tersebut. Karena semakin banyak penerimaan, maka 
semakin banyak terdapat hak-hak orang lain di dalamnya. Oleh karena itu, jika zakat tersebut dikelola dengan penguatan tata kelola zakat melalui pelaksanaan prinsip-prinsipnya serta tetap memperhatikan ketentuan syariah, maka pencapaian tujuan zakat akan lebih mudah dan akan dapat memberikan hasil yang lebih optimal untuk mustahiq.

Sehubungan dengan fenomena pengelolaan zakat sebagaimana yang telah diuraikan. penulis merasa tertarik untuk mengkaji lebih mendalam mengenai tata pengelolaan zakat yang baik di lembaga zakat melalui penekanan pada prinsip-prinsip good governance secara komprehensif serta tetap mengedepankan karakteristik lembaga zakat sebagai lembaga yang disyariatkan. Prinsip-prinsip good governance di sini dilihat dari perspektif Qardhawi, yakni pada prinsip-prinsip yang secara implisit tersirat dalam pandangan zakat Qardhawi dan relevan dengan prinsipprinsip good governance. Qardhawi telah menetapkan pandangannya mengenai zakat secara mendalam dan menyeluruh menyelaraskan perkembangan problematika zakat di era kontomporer. Cakupan penelitian ini ialah pengelolaan zakat yang lebih difokuskan pada pendistribusian dan pendayagunaanya, karena aspek ini lebih penting (untuk diperhatikan) daripada aspek pengumpulannya. ${ }^{15}$

Berdasarkan sejumlah hal sebagaimana dalam uraian di atas, maka semakin mendukung dan memotivasi peneliti dalam rangka menjawab pertanyaan penelitian ini, yakni "Bagaimana prinsip-prinsip good governance pada pengelolaan dana zakat di Baitul Mal Kabupaten Aceh Tengah ditinjau dari perspektif Qardhawi ?” Penelitian ini bertujuan untuk menggambarkan prinsip-prinsip good governance pada pengelolaan dana zakat di Baitul Mal Kabupaten Aceh Tengah dalam perspektif Qardhawi.

\section{Metode Penelitian}

Tulisan ini merupakan suatu penelitian studi kasus dengan metode kualitatif. Penelitian kualitataif dimaksudkan untuk memahami suatu fenomena mengenai hal yang dialami subjek penelitian seperti perilaku, tindakan, motivasi, persepsi dan lainnya secara holistik, dengan cara yang deskriptif. ${ }^{16}$ Studi kasus di sini digunakan untuk menggambarkan prinsip-prinsip good governance lembaga pengelola zakat dalam melaksanakan pengelolaan zakat, terutama pada pendistribusian dan pendayagunaannya. Data yang dibutukan dalam penelitian ini berdasarkan di

15 Ugi Suharto, Zakat Sebagai Lembaga Keuangan Publik Khusus: Refleksi Kitab Al Amwal Karya Abu Ubaid. Zakat \& Empowering-Jurnal Pemikiran dan Gagasan. Vol. 2: 2009, h. 10

16 Lexy J. Moleong, Metodologi Penelitian Kualitatif, (Bandung: Remaja Rosdakarya, 2011), h. 6 
antara sumber bukti (data) pada penelitian studi kasus. ${ }^{17}$ Data diperoleh peneliti berdasarkan fenomena-fenomena yang diamati serta melalui proses interaksi (wawancara) dengan beberapa informan terpilih. Data juga diperoleh atau sudah tersedia sebelum pelaksanaan penelitian seperti melalui buku-buku, artikelartikel ilmiah, serta pada saat penelitian seperti dokumen resmi, peraturan dan laporan. Langkah yang dilakukan dalam analisis pembahasan pada penelitian ini sebagaimana gambar 1. Data hasil wawancara beserta hasil pengamatan dan dari studi dokumentasi kemudian direduksi. Lalu dilakukan pengkategorisasian data sesuai dengan prinsip-prinsip good governance yang secara implisit tersirat dalam pandangan zakat perspektif Qardhawi. Prinsip-prinsip tersebut meliputi prinsip syariah, amanah, keadilan, akuntabiltas, transparansi, profesionalitas, partisipasi, dan efisiensi. Dalam langkah tersebut diikuti dengan penafsiran atau pemaknaan terhadap data dengan menghubungkan atau meninjaunya dari sudut pandang (perspektif) Qardhawi tersebut.

Gambar 1. Teknis Analisis dalam Pembahasan

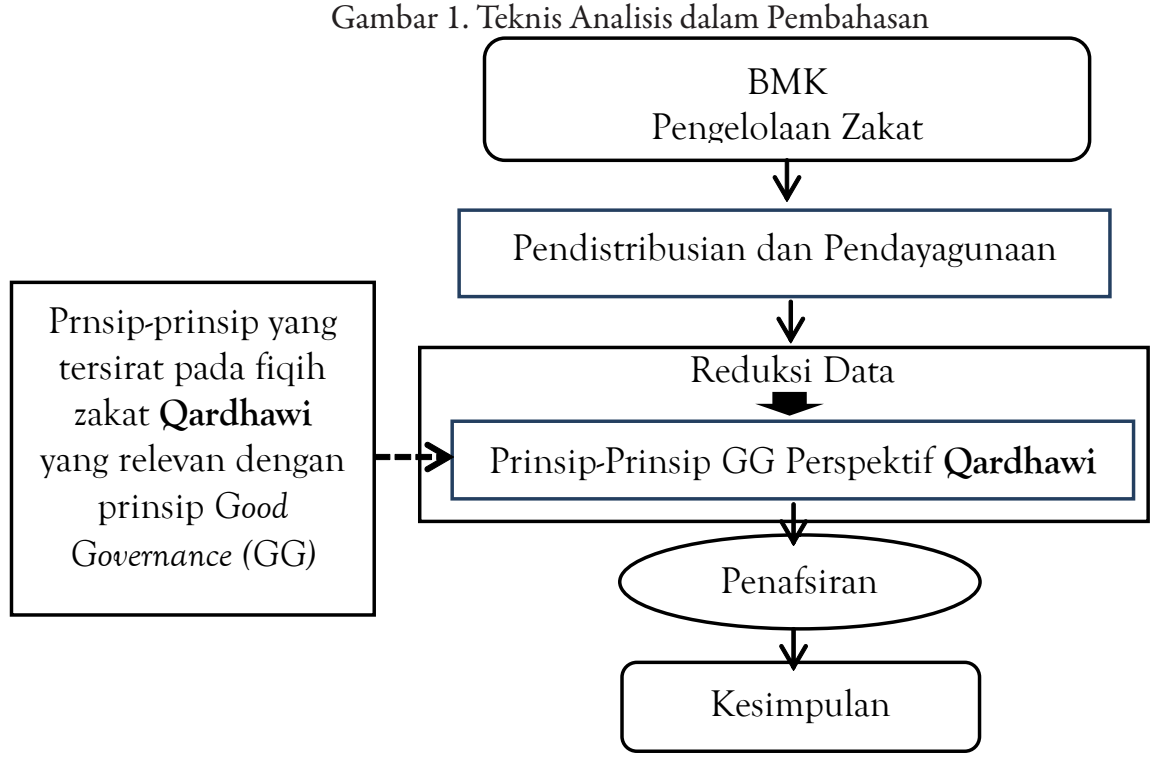

\section{Pembahasan}

\section{Sekilas Tinjauan Good Governance dalam Konteks Umum}

Istilah governance sering disebutkan dalam berbagai hal atau kesempatan dan dimaknai secara berlainan. ${ }^{18}$ Demikian juga mengenai prinsip-prinsip yang

17 Robert K. Yin, Studi Kasus: Desain dan Metode, Cet. 14 (Jakarta: Rajawali Pers, 2002), h. 103

18 Haryanto \& Sahmuddin \& Arifuddin. Akuntansi Sektor Publik, Edisi Pertama (Semarang: Badan Penerbit UNDIP, 2007), h. 7 
melandasinya begitu bervariasi. ${ }^{19}$ Pelembagaan governance secara global sudah dimulai tahun 1992 oleh cadbury committee, kemudian OECD (Organisation for Economic Co-Operation and Development) di tahun $1999 .{ }^{20}$ Di Indonesia, dimulai para tahun 1999 melalui KNKG (Komite Nasional Kebijakan Governance). Kata governance kemudian berkembang menjadi popular dengan sebutan kepemerintahan, yang juga mengandung arti sebagai suatu kegiatan, pengurusan, pengelolaan, pengarahan, pembinaan, dan penyelenggaraan. ${ }^{21}$ LAN (Lembaga Administrasi Negara) menyebut governance sebagai kepemerintahan, dan praktek terbaiknya diistilahkan dengan good governance. ${ }^{22}$ Kepemerintahan (governance) tidak sama dengan pemerintahan (government). Kepemerintahan bermakna lebih luas, meliputi seluruh unsur kelembagaan yang didalamnya termasuk pemerintah, swasta, dan masyarakat. UNDP (United Nations Development Programme) menyebutkan sembilan prinsip-prinsip good governance, yakni adanya partisipasi, supremasi hukum, transparansi, responsibilitas, orientasi pada konsensus, kesetaraan, efektif dan efisien, akuntabilitas, dan visi strategis. ${ }^{23}$ OECD merumuskan enam prinsipprinsip governance, namun lebih mengarah pada konteks korporasi. ${ }^{24}$ Indonesia juga mengungkapkan prinsip-prinsip good governance seperti dalam KNKG, MTI (Masyarakat Transparansi Indonesia), dalam Peraturan Pemerintah No. 101 Tahun 2000, dan lainnya.

\section{Kandungan Prinsip-Prinsip Good governance dalam Fiqih Zakat Qardhawi}

Sebagaimana disebutkan di awal, bahwa prinsip-prinsip good governance dalam penelitian ini merujuk pada prinsip-prinsip dalam pengelolaan zakat persepktif Qardhawi. Secara gamblang tidak ditemukan prinsip-prinsip good governance dalam pandangan zakat Qardhawi. Namun penulis coba mengangkat prinsip-prinsip yang secara tidak langsung tersirat dalam fiqih zakat Qardhawi dan relevan dengan prinsip-prinsip good governance. Alasan penulis menggunakan

19 Jumaizi \& Zainal A Wijaya, Good Governance BAZIS, h. 128

20 Mal An Abdullah, Corporate Governance Perbankan Syariah di Indonesia (Yogyakarta: Ar-Ruzz Media, 2010), h. 25

21 Sedarmayanti, Good Governance "Kepemerintahan Yang Baik" Bag. Kedua: Membangun Siatem Manajemen Kinerja Guna Meningkatkan Produktifitas (Mandar Maju. Bandung, 2004), h. 36

22 LAN, Sosialisasi Sistem Akuntabilitas Kinerja Instansi Pemerintah (AKIP), modul 1 "Akuntabilitas dan Good Governance". Jakarta: Cetakan Pertama-Maret, 2000, h. 1

23 UNDP, Governance for Sustainable Human Development. A UNDP Policy Document, 1997

24 OECD, Principles of Corporate Governance (Paris, OECD Publications Service, 2004), h. 17 
pandangan Qardhawi ialah kerena, di antara salah satu karya besar Qardhawi yang menjadi rujukan luas saat ini adalah fikih zakat. Pandangan Qardhawi mengenai zakat secara mendalam ditujukan untuk menjawab masalah-masalah zakat kontemporer, di mana masalah-masalah tersebut sangat mempengaruhi keberhasilan zakat dalam merealisasikan tujuan untuk umat. Berikut kandungan prinsip-prinsip good governance dalam fiqih zakat Qardhawi:

Pertama, prinsip syariah: "Pendirian lembaga zakat atau pembentukan Undang-undang yang mengatur pengumpulan dan juga pendistribusiannya zakat haruslah menjadi bagian yang sempurna dalam penerapan hukum Islam". ${ }^{25} \mathrm{Hal}$ ini menunjukan bahwa, amil atau pengelola zakat dituntut untuk bersungguhsungguh dalam mengelola zakat dengan berlandaskan kepada hukum Islam (syariah). Begitu juga dengan peraturan atau perundangan dalam mengelola zakat, harus relevan dengan syariah.

Kedua, prinsip amanah: Dana zakat merupakan harta milik Allah yang harus dikelola dan digunakan berdasarkan amanah-Nya yang termaktub dalam Al-Quran, yakni pada Surah At-Taubah: 60. “Tidak seyogianya mencampuradukan uang kharraj (upeti/pajak) ke dalam uang zakat. Karena uang pajak diperuntukan bagi semua kaum, sementara zakat hanya diperuntukan untuk golongan tertentu". ${ }^{26}$ Hal ini menunjukan bahwa zakat tidak boleh disatukan dengan dana lain seperti dari sumber pajak, karena dana zakat telah jelas peruntukannya, tidak seperti pajak yang dapat dikeluarkan untuk keperluan negara yang bersifat umum dan luas di berbagai macam program dan sasaran.

Ketiga, prinsip keadilan: "Hendaklah zakat itu didistribusikan pada tempat di mana zakat tersebut ditemukan". ${ }^{27},{ }^{28} \mathrm{Jika}$ ada kelebihan pada suatu daerah agar didistribusikan pada daerah lain yang pengumpulan zakatnya sedikit, karena bisa jadi di sana lebih banyak fakir miskin. ${ }^{29} \mathrm{Hal}$ ini menunjukan bahwa zakat sebaiknya disalurkan ke wilayah di mana zakat dikumpulkan. Apabila di daerah asal tersebut terdapat kelebihan atau tidak ada lagi yang membutuhkan zakat, diperbolehkan penyalurannya keluar daerah demi kemaslahatan umat. Kemudian, pendistribusian yang baik adalah keadilan di antara semua golongan. Adil di sini bukanlah ukuran

25 Yusuf Qardhawi, Spektrum Zakat dalam Membangun Ekonomi Kerakyatan. Terjemahan oleh Sari Narulita (Jakarta: Zikrul Hakim, 2005), h. 161

26 Yusuf Qardhawi, Spektrum..., h. 129

27 Yusuf Qardhawi, Spektrum..., h. 141

28 Yusuf Qardhawi, Hukum Zakat. Terjemahan oleh Salman Harun, Didin Hafidhuddin, dan Hasanuddin (Bogor: Pustaka Litera Antar Nusa, 2002), h. 799

29 Yusuf Qardhawi, Spektrum..., h. 140 
yang sama, tetapi untuk menjaga kepentingan umat. ${ }^{30} \mathrm{Hal}$ ini menunjukan bahwa dalam pembagian zakat di setiap golongannya (asnaf) dilakukan dengan adil, bukan dengan memberikan ukuran yang sama pada setiap golongan, melainkan melihat kemaslahatannya.

Keempat, prinsip akuntabilitas: Di antara syarat yang mengiringi kesuksesan zakat ialah "Administrasi yang accountable". ${ }^{31}$ Accountable adalah kata sifat dari accountability (akuntabilitas). ${ }^{32}$ Kemudian, di antara hal terkait dengan urusan zakat ialah terdapatnya bagian bendahara dan bagian pencatatan. ${ }^{33}$ Pencatatan sebagai salah satu bagian dari pekerjaan dalam administrasi merupakan hal yang penting dalam pelaksanaan zakat. Karena pencatatan transaksi yang tepat atau sesuai dengan keadaan pada akhirnya akan memberikan kekuatan untuk dapat dipertanggungjawabkan. ${ }^{34}$ Dari sini dapat diangkat suatu prinsip akuntabilitas, yakni pertanggungjawaban atas pengelolaan dana zakat melalui pelaporan (hasil pencatatan) yang dapat dipertanggungjawabkan. Di mana pertanggungjawaban tersebut nantinya ditujukan kepada masyarakat (terutama muzaki), pemerintah, dan lainnya.

Kelima, prinsip transparansi: Adanya ketidakpercayaan publik terhadap lembaga zakat, akan menimbulkan kecurigaan dan menjadikan penilaian yang negatif. "Tidak adanya kepercayaan terhadap pemerintah yang bertugas untuk mengumpulkan zakat karena mengira bahwa pemerintah tidak mendistribusikannya sebagaimana yang telah ditetapkan dalam hukum Islam". ${ }^{35}$ Dengan demikian, agar pengelolaan zakat dapat memberikan kepercayaan kepada publik, maka penyelenggaaraan zakat harus transparan (bersifat terbuka). Karena, melalui transparansi informasi dapat dihindari ketidakpercayaan masyarakat pada lembaga pengelola zakat dalam mengelola dana-dana yang telah diamanahkan. ${ }^{36}$

30 Yusuf Qardhawi, Spektrum..., h. 148

31 Yusuf Qardhawi, Spektrum..., h. 123

32 Akuntabilitas diartikan sebagai suatu pertanggungjawaban atas pengelolaan sumber daya/

perusahaan, kegiatan, penyelenggaraaan, pekerjaan, atau tugas. (www.kamusbesar.com).

33 Yusuf Qardhawi, Hukum Zakat, h. 545

34 Dalam QS Al-Baqarah:282 tersirat perintah penulisan (pencatatan) dari setiap transaksi, sehingga dapat memberikan kekuatan untuk dapat dipertanggungjawabkan.

35 Yusuf Qardhawi, Spektrum..., h. 163

36 Sejalan dengan penyebab ketidakpercayaan muzaki terhadap lembaga zakat sebagaimana yang dinyatakan dalam Kemenag (2012), "Ketidakpercayaan masyarakat terhadap lembaga yang mengelola zakat, lebih disebabkan oleh kesenjangan informasi antara pihak lembaga yang memiliki akses langsung terhadap informasi dengan pihak konstituen atau masyarakat yang berada di luar lembaga”. 
Keenam, prinsip profesionalitas: Untuk mengiringi kesuksesan zakat adalah dikelola oleh para penanggung jawab (amil) yang profesional. Dalam rangka mengarahkan maksud tersebut, maka harus dilakukan "Pemilihan SDM terbaik untuk menempati lembaga zakat" ${ }^{37}$ Terdapat beberapa syarat bagi SDM (Sumber Daya Manusia) sebagai amil, yakni "Seorang muslim, mukallaf, jujur, memahami hukum zakat, mampu untuk melaksanakan tugas, sebaiknya laki-laki, serta merdeka (bukan hamba sahaya)". ${ }^{38} \mathrm{Hal}$ ini menunjukan bahwa diperlukan beberapa kriteria SDM amil sebagaimana tersebut di atas, agar pelaksanaan zakat dapat dilakukan secara profesional. Poin yang berperan begitu penting dalam membentuk identitas profesional dalam konteks zakat adalah pemahaman atas hukum zakat. Hal ini dikarenakan agar dalam pengelolaan zakat dapat berjalan sesuai dengan karakteristik lembaga pengelola zakat sebagai lembaga yang memiliki muatan syariah terkait zakat.

Ketujuh, prinsip partisipasi: Hendaklah zakat baru diberikan setelah adanya keyakinan dan kepercayaan bahwa mustahiq adalah orang yang berhak. "Hal ini dapat dilakukan dengan cara mengetahui atau menanyakannya pada orangorang yang tinggal dilingkungannya atau yang mengetahui keadaan sebenarnya." ${ }^{39}$ Keadaan ini menunjukan pentingnya peran atau partisipasi orang-orang yang lebih mengetahui siapa saja yang berhak atas zakat di sekitar mereka. Kemudian, "Realisasi zakat akan sulit dijalankan pada wilayah di mana masyarakatnya meremehkan musyawarah di antara mereka". ${ }^{40} \mathrm{Hal}$ ini menunjukan bahwa musyawarah dapat dijadikan sebagai suatu wahana untuk aktifitas dalam proses mempermudah merealisasikan penyaluran dana zakat, termasuk di dalamnya terdapat tahapan untuk menentukan penerima yang berhak dalam rangka penyaluran zakat agar tepat pada sasaran.

Kedelapan, prinsip efisiensi: Qardhawi juga mengarahkan agar dilakukan penghematan (efisiensi), yakni "Hemat dalam pengeluaran administratif sebaik mungkin" ${ }^{41}$ Biaya administrasi atau operasional dapat diambilkan dari dana amil. Kemudian, "Hendaknya amil diberi upah sesuai dengan pekerjaannya, tidak terlalu kecil dan tidak juga berlebihan". ${ }^{42}$ Besaran alokasi untuk amil adalah seperdelapan

37 Yusuf Qardhawi, Spektrum Zakat dalam, h. 123

38 Yusuf Qardhawi, Hukum Zakat, h. 551-555

39 Yusuf Qardhawi, Spektrum Zakat dalam, h. 152

40 Yusuf Qardhawi, Spektrum Zakat dalam, h. 159

41 Yusuf Qardhawi, Spektrum Zakat dalam, h. 130

42 Yusuf Qardhawi, Hukum Zakat, h. 556 
bagian dari zakat yang terhimpun. ${ }^{43}$ Jika upah (insentif atau honor amil) lebih besar dari bagian tersebut, haruslah diambil dari harta di luar zakat. ${ }^{44}$ Oleh karena itu, dalam pengelolaan zakat hendaklah dilakukan secara efisien terhadap biaya operasional atau administrasi yang diambil dari dana amil zakat. Selain itu terdapat pembatasan penggunaan dana amil dari sumber zakat sebagaimana batasan besaran dana amil seperti tersebut di atas. Sehingga pengelolaan zakat dapat dilaksanakan dengan memprioritaskan dana zakat untuk sasaran utamanya, yakni fakir dan miskin.

Berdasarkan pada uraian prinsip-prinsip di atas, dapat disajikan dalam suatu ringkasan pada tabel berikut:

Tabel 2. Ringkasan Kandungan Prinsip-Prinsip Good governance dalam Fiqih Zakat Qardhawi

\begin{tabular}{|c|c|c|c|}
\hline No & $\begin{array}{l}\text { Prinsip dalam } \\
\text { Qrdhawi }\end{array}$ & Deskripsi & Indikator \\
\hline 1 & Prinsip Syariah & $\begin{array}{l}\text { Pelaksanaan pengelolaan dan } \\
\text { perundangan terkait zakat harus } \\
\text { berlandaskan syariah. }\end{array}$ & $\begin{array}{l}\text { Pengelolaan secara syariah } \\
\text { Perundangan relevan syariah }\end{array}$ \\
\hline 2 & $\begin{array}{l}\text { Prinsip } \\
\text { Amanah }\end{array}$ & $\begin{array}{l}\text { Zakat tidak boleh dicampur } \\
\text { dengan lainnya dan tidak } \\
\text { diperuntukan bagi keperluan di } \\
\text { luar sasaran zakat. }\end{array}$ & $\begin{array}{l}\text { Peruntukan sesuai sasaran } \\
\text { Penempatannya khusus }\end{array}$ \\
\hline 3 & $\begin{array}{l}\text { Prinsip } \\
\text { Keadilan }\end{array}$ & $\begin{array}{l}\text { Distribusi zakat secara adil di } \\
\text { setiap wilayah dan setiap asnaf. } \\
\text { Adil di sini bukan membagi sama, } \\
\text { tetapi melihat kemaslahatan. }\end{array}$ & $\begin{array}{l}\text { Adil setiap wilayah } \\
\text { Adil untuk asnaf }\end{array}$ \\
\hline 4 & $\begin{array}{l}\text { Prinsip } \\
\text { Akuntabilitas }\end{array}$ & $\begin{array}{l}\text { Administrasi pengelolaan } \\
\text { dana zakat yang dapat } \\
\text { dipertanggungjawabkan. }\end{array}$ & $\begin{array}{l}\text { Pencatatan setiap transaksi } \\
\text { Laporan } \\
\text { pertanggungjawaban }\end{array}$ \\
\hline 5 & $\begin{array}{l}\text { Prinsip } \\
\text { Transparansi }\end{array}$ & $\begin{array}{l}\text { Keterbukaan informasi atas } \\
\text { pengelolaan dana zakat untuk } \\
\text { meningkatkan kepercayaan } \\
\text { publik. }\end{array}$ & Keterbukaan atas informasi \\
\hline 6 & $\begin{array}{l}\text { Prinsip } \\
\text { Profesional }\end{array}$ & $\begin{array}{l}\text { Pengelolaan zakat dilakukan } \\
\text { secara profesional melalui } \\
\text { pemilihan SDM amil yang } \\
\text { memiliki kriteria tertentu. }\end{array}$ & $\begin{array}{l}\text { [utamanya] Memahami } \\
\text { hukum zakat }\end{array}$ \\
\hline 7 & $\begin{array}{l}\text { Prinsip } \\
\text { Partisipasi }\end{array}$ & $\begin{array}{l}\text { Adanya partisipasi pihak-pihak } \\
\text { dalam masyarakat agar penyaluran } \\
\text { zakat lebih tepat pada sasarannya. }\end{array}$ & $\begin{array}{l}\text { Adanya partisipasi } \\
\text { masyarakat } \\
\text { Musyawarah }\end{array}$ \\
\hline
\end{tabular}

43 Yusuf Qardhawi, Hukum Zakat, h. 672

44 Yusuf Qardhawi, Hukum Zakat, h. 556 


\begin{tabular}{llll}
\hline 8 & Prinsip & Penghematan dalam & Batasan dana amil \\
& Efisiensi & Altaksanakan pengelolaan zakat & Antuk penggunaan biaya-biaya \\
& & \\
& & \\
& & \\
\hline
\end{tabular}

\section{Analisis Pembahasan}

Bagian ini merupakan uraian analisis pembahasan atas hasil penelitian sesuai dengan fokus penelitian, yakni deskripsi prinsip-prinsip good governance dalam pengelolaan zakat di Baitul Mal Kabupaten (BMK) Aceh Tengah dilihat prinsipprinsip good governance yang tersirat dalam fiqih zakat Qardhawi sebagaimana pada tabel 2.

\section{Prinsip syariah}

Pengelolaan zakat di BMK dilaksanakan dengan menyesuaikan pada ketentuan syariah. Dalam konteks pendistribusian dan pendayagunaan, merujuk pada AlQuran maupun Hadis. BMK menyusun program dalam satu tahun anggaran dengan tetap mengacu pada delapan asnaf yang ada dalam QS At-Taubah: 60. Hanya saja, dalam pelaksanaannya menyesuaikan perkembangan fiqih. Sehingga program pendistribusian dan pendayagunaan zakat di BMK menjadi cukup variatif, penyaluran yang tidak hanya untuk konsumtif tetapi juga dalam bentuk produktif. Disamping itu, program-program zakat pada BMK merupakan perwujudan dari adanya perluasan makna di antara beberapa asnaf dengan mengikuti perkembangan zakat kontemporer. Berikut uraian program BMK sebagaimana dimaksud:

1. Bantuan modal usaha mustahiq, diprioritaskan kepada asnaf fakir miskin dalam bentuk modal usaha pertanian, ternak, dagang, nelayan, dan lainya. Tujuannya adalah untuk meningkatkan pendapatan mereka.

2. Pembinaan keterampilan putera/puteri dari mustahiq (terutama asnaf fakir miskin) yang putus sekolah. Kegiatannya adalah dalam bentuk pelatihan menjahit pakaian, border kerawang (motifkhas suku asli Aceh Tengah/suku Gayo) bagi anak puteri. Sementara bagi putera diberikan pelatihan las dan bengkel. Tujuannya agar mereka dapat berusaha mandiri di kemudian. Kepada mereka diberikan honor pelatihan beserta perlengkapan/ alat keperluan sesuai jenis pelatihan.

3. Bantuan asnaffakir yang sudah uzur, yakni fakir yang tidak dapat lagi berusaha, sementara anak dari keluarganya tidak dapat membantu mereka kerena juga miskin setiap bulan selama hayatnya sebesar Rp. 500.000,00.

4. Beasiswa putra/putri dari mustahiq (terutama asnaf fakir miskin) mulai pendidikan SD s/d S1, baik di dalam daerah maupun ke luar daerah. Tujuannnya adalah untuk meretas rantai kemiskinan orang tua kepada anak-anaaknya. 
Disamping itu, disediakan juga bantuan beasiswa S2/S3 kepada mereka yang berkualitas menempuh pendidikan di luar daerah dalam rangka usaha meningkatkan kualitas manusia sebagaimana visi BMK.

5. Membantu lembaga pendidikan non pemerintah melalui asnaf fisabilillah, untuk menunjang kegiatan pesantren, dayah, majelis ta'lim, TPA, serta PTS non pemerintah. Tujuanya adalah untuk meningkatkan kualitas peserta didik/pembelajaran dalam rangka meningkatkan kualitas manusia terutama untuk memahami Al Quran dan As Shunah.

6. Membantu menjaga kemakmuran dan fungsi tempat ibadah, melalui pembangunan atau perbaikan tempat ibadah. Sehingga syiar Islam berkembang melalui masjid atau mushala.

7. Membangun atau memperbaiki rumah mustahiq yang tidak layak huni, seperti rumah dalam bentuk balutan plastik, tepas, kardus, ilalang, daun, atau rumah papan lapuk. Rumah yang telah dibangun nantinya tidak dapat dialihkan kepada pemilik baru dengan cara apapun, kecuali kepada ahli warisnya.

8. Membantu pendidikan para hafidz/hafidzhah dan qari/'ah, yang sedang mengikuti pendidikan baik di dalam maupun ke luar daerah dengan tujuan mencetak generasi lebih berahlak dan berkembang di masa datang.

9. Infak produktif, berupa modal usaha kepada mereka yang dililit izon (rentenir) serta untuk pembanguan aset Baitul Mal untuk menambah sumber penerimaan infak.

Sehubungan dengan pelaksanaan ketentuan zakat sebagi PAD (Pendapatan Asli Daerah), mengharuskan BMK ikut dalam aturan dan mekanisme keuangan daerah. Oleh karena itu, disamping mengikuti aturan hukum Islam (syariah), BMK turut menerapkan aturan positif yang berhubungan dengan pengelolaan zakat dari aspek keuangannya. Hal ini menjadikan kendala bagi BMK, misalnya dalam hal proses pencairan dana zakat yang telah disetor ke Kas Daerah membutuhkan prosedural dan waktu yang tidak bisa dikatakan cepat. Hal ini dapat berpeluang pada terjadinya penundaan atau terhambatnya penyaluran zakat pada BMK. Sementara secara syariah, zakat harus senantiasa siap dengan segera dan tidak boleh ditunda penyalurannya terutama untuk fakir miskin. ${ }^{45}$

\section{Prinsip amanah}

Zakat yang dikelola BMK hanya diperuntukan bagi fakir dan miskin,

45 Yusuf Qardhawi, Hukum Zakat, h. 811 
serta mustahiq (penerima) lainnya sesuai dengan asnaf sasaran zakat yang telah diamanahkan dalam QS At-Taubah:60. Dana zakat pada BMK tidak diperuntukan bagi kepentingan-kepentingan lainnya di luar sasaran zakat tersebut. Meskipun dana zakat yang dikelola BMK terlebih dahulu dimasukan sebagai PAD, akan tetapi dana zakat tidak dicampur dengan penerimaan daerah yang bersumber dari pajak, retribusi, dan lainnya. Zakat yang disetor oleh BMK ke Kas Daerah ditampung dalam suatu rekening khusus yang hanya diperuntukan bagi dana zakat yang kewenangan pengelolaannya dilaksanakan oleh BMK. Hal tersebut sebagaimana yang telah ditegaskan dalam Qanun Aceh No. 10 Tahun 2007 tentang Baitul Mal, yakni pada Pasal 25 ayat (3) yang berbunyi "PAD Kabupaten/Kota sebagaimana dimaksud pada ayat (2) disimpan dalam rekening tersendiri Bendaharawaan Umum Daerah (BUD) Kabupaten/Kota yang ditunjuk Bupati/Walikota”.

\section{Prinsip keadilan}

BMK mengalokasikan dana zakat yang telah dihimpun kepada wilayah (Kampung) di mana zakat itu diperoleh, ditambah dengan dana zakat yang diperoleh BMK dari penerimaan zakat Kabupaten. Penambahan kepada tiap-tiap Kampung disesuaikan dengan keadaan dan banyaknya mustahiq di setiap Kampung. Pembagian dengan cara seperti ini dilakukan oleh BMK untuk menghindari kesenjangan berlebihan yanga ada di setiap wilayah. Selain itu, BMK mengalokasikan zakat pada semua asnaf yang terdapat dalam ketentuan syariah. Kecuali asnaf Riqab (hamba sahaya), dikarenakan asnaf ini sulit untuk ditemukan saat ini. Alokasi pembagian zakat untuk setiap asnaf ditunjukan pada tabel 3. Tampak bahwa BMK memberikan alokasi terbesar pada asnaf fakir miskin. Hal ini sebagaimana tujuan utama dari zakat yakni memberi kecukupan kepada mereka. ${ }^{46}$

Tabel 3. Alokasi Zakat Setiap Asnaf pada BMK

\begin{tabular}{llr}
\hline No & Asnaf & Persentase (\%) \\
\hline 1 & Fakir & 35,0 \\
\hline 2 & Miskin & 23,0 \\
\hline 3 & Amil & 15,0 \\
\hline 4 & Mualaf & 0,5 \\
\hline 5 & Riqab (hamba sahaya) & 0 \\
\hline 6 & Gharim & 0,5 \\
\hline 7 & Sabilillah & 24,0 \\
\hline 8 & Ibnu sabil & 2,0 \\
\hline & & 100,0 \\
\hline
\end{tabular}

46 Yusuf Qardhawi, Hukum Zakat, h. 671 
Sumber: Laporan Baitul Mal 2015

\section{Prinsip akuntabilitas}

Akuntabilitas pada BMK adalah pertanggungjawaban atas pengelolaan dana zakat, terutama mengenai penggunaan dana tersebut. Salah satu informan mengemukakan bahwa, pertanggungjawaban BMK yang paling utama adalah kepada Allah SWT, karena IA sebagai pemilik utama atas harta zakat. Berikut petikan wawancaranya:

"Pada dasarnya kita harus bertanggungjawab pertama kepada Allah SWT, pemilik dari dana ini. Selanjutnya dari sisi kelembagaan, sebagai institusi publik kita bertanggung jawab kepada pemerintah melalui laporan yang kita berikan, lalu kepada muzaki yang telah memberikan atau menyetorkan zakatnya, kemudian kepada mustahiq".

Dalam pelaksanaan tugas pokok dan fungsi sebagai bagian dari institusi publik yang mengelola dana umat, bentuk pertanggungjawaban BMK adalah dituangkan dalam bentuk laporan. Untuk membuat pertanggungjawabannya, diawali dari proses pencatatan atas transaksi pengeluaran (penggunaan) oleh bagian keuangan pengeluran BMK. Berdasarkan bukti-bukti pada setiap transaksi pengeluaran di setiap harinya, dilakukan pencatatan ke dalam buku kas pada aplikasi MS Excel. Pelaksanaan pencatatan tersebut merupakan dasar untuk laporan, sebagai wujud pertanggungjwaban BMK kepada publik. Berikut pola pelaporan pertanggungjawaban BMK terhadap stakeholder zakat:

Tabel 4. Pola Pelaporan Pertanggungjawaban atas Pengelolaan Dana Zakat

\begin{tabular}{lllll}
\hline No & Erekuensi & \multicolumn{2}{c}{ Sasaran } & \multicolumn{1}{c}{ Keterangan } \\
\hline 1 & Bulanan & Kepala BMK & Laporan kas bulanan \\
\hline 2 & Triwulan & Bupati, DPRK & (Dewan & Laporan kas triwulan \\
& & Perwakilan & Rakyat & \\
& & Kabupaten) & \\
\hline 3 & Tahunan & $\begin{array}{l}\text { Masyarakat (melalui Baitul } \\
\\
\end{array}$ & Mal Kampung), Tiap-tiap & Laporan Tahunan \\
& & Instansi, Baitul Mal Aceh, & \\
& & Bupati, DPRK, dan Baznas & \\
\hline
\end{tabular}

Sumber: Data diolah, hasil wawancara dengan para Informan

Namun demikian, BMK membuat laporannya belum didukung oleh aplikasi sistem akuntansi zakat yang lebih memadai untuk memudahkan pencatatan dan menghasilkan laporan yang lebih akuntabel. Selain itu, laporan yang dipublikasikan oleh BMK masih cukup sederhana, misalnya untuk laporan triwulanan hanya 
berupa perkembangan dana masuk dan pengeluaran serta sisa saldo pada periode tersebut.

\section{Prinsip transparansi}

BMK telah memberikan akses terhadap informasi perkembangan dana zakat melalui beberapa media seperti radio RRI, running text, spanduk, dan TV lokal (Gayo-TV). BMK juga mempublikasikan informasi program-program yang telah dipersiapkan (seperti beasiswa, modal usaha, dan lainnya). Disamping itu dilakukan pengumuman di masjid-masjid pada setiap hari jumat sebelum pelaksanaan khutbah. Untuk informasi melalui radio dan TV lokal, disiarkan pada setiap harinya dengan pemutakhiran data setiap enam bulan. Pembaharuan spanduk juga dilakukan setiap enam bulan, serta pemutakhiran data pada running text setiap tiga bulan. Namun demikian, BMK hanya memberikan informasi atau pengumuman atas perkembangan dana zakat secara pokok, seperti jumlah penerimaan dan pengeluran (penggunaan dana), dan sisa saldo pada periode bersangkutan. Selain itu, BMK juga masih belum memanfaatkan keberadaan sistem berbasis teknologi informasi sebagai media untuk memberikan akses informasi yang lebih luas, lebih mudah, lebih fleksibel, dan lebih efektif dalam rangka memenuhi kebutuhan informasi publik saat ini, misalnya melalui penggunaan halaman website.

\section{Prinsip profesionalitas}

Agar pelaksanaan zakat dapat dilaksanakan secara profesional, dibutuhkan SDM dengan kriteria yang hendaknya relevan dengan konteks zakat. Sebagaimana kriteria SDM amil yang disebutkan dalam Qardhawi, ${ }^{47}$ di antara poin yang begitu penting dalam perannya terhadap permasalahan zakat adalah pemahaman atas hukum zakat. Hal ini dimaksudkan agar pelaksanaan pengelolaan zakat dapat dilakukan secara profesional dalam kaidah zakat yang sesuai syariah. Jika dilihat dari poin tersebut, secara umum kualifikasi SDM pengelola zakat (amil) yang ada di BMK masih kurang memenuhi. Karena dalam rangka pelaksanaan pengelolaan zakat di BMK tidak diberlakukan kualifikasi yang baku bagi amil. Proses rekruitmen tidak begitu memperhatikan kompetensi amil, sehingga hanya terdapat beberapa orang yang berasal dari latar belakang pendidikan yang relevan dengan zakat.

Tabel 5. Rekapitulasi SDM Amil BMK

\begin{tabular}{|c|c|c|c|c|}
\hline No & Usia & Masa Kerja & Latar Belakang & Jenis \\
\hline 1 & $<30 \mathrm{Th}$ & $<2 \mathrm{Th}$ & Agama 3 & \begin{tabular}{l|l} 
LK & 11 \\
\end{tabular} \\
\hline
\end{tabular}

47 Yusuf Qardhawi, Hukum Zakat, h. 551-555 


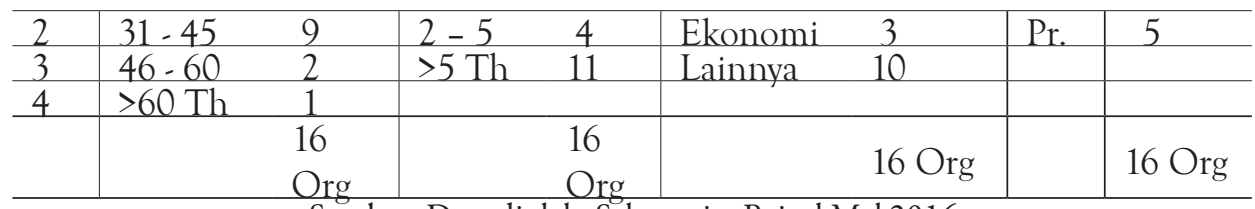

Sumber: Data diolah, Sekretariat Baitul Mal 2016

Pada tabel 5 menunjukan bahwa, sebagian besar amil adalah orang-orang yang sudah cukup lama bertugas di BMK, yakni selama diatas lima tahun. Sehingga diharapkan pengalaman yang dimiliki para amil dapat memberikan nilai tambah dalam mendukung pengelolaan zakat secara profesional. Selain itu, sebagian besar amil pada BMK merupakan kaum laki-laki, sehingga dapat mengantisipasi keterbatasan dalam aktifitas zakat, terutama dalam hal yang berkaitan dengan teknis di lapangan seperti pelaksanaan penelitian mustahiq, memantau perkembangan atau permasalahan mustahiq, dan lainnya.

\section{Prinsip partisipasi}

Dalam rangka proses pendistribusian dan pendayagunaan dana zakat, BMK tidak terlepas dari partisipasi beberapa pihak yakni dari unsur Kampung (kepala Kampung, Imam Kampung merangkap kepala Baitul Mal Kampung, sekretaris, dan lainnya) serta dari unsur Dusun (Imam Dusun, dan lainnya). Mereka diberi kepercayaan oleh BMK dalam menentukan penerima zakat yang berhak di wilayahnya masing-masing. Hal tersebut dikarenakan pada alasan bahwa mereka lebih mengetahui kondisi dan keberadaan dari masyarakat di wilayahnya yang membutuhkan dan perlu untuk diberikan bantuan. Penentuan penerima zakat yang berhak dilakukan melalui musyawarah di antara mereka. Berikut petikan wawancara dengan salah satu informan mengenai hal tersebut:

"Dalam pendataan, jika dilaksanakan oleh BMK dengan jumlah Kampung dan penduduk cukup banyak, BMK tidak mampu mendata secara langsungke lapangan. Kita berikan amanat itukepada pengurus Kampungagar mereka mendata, melakukan musyawarah untuk memastikan siapa saja yang didata di sana dan ditetapkan dalam musyawarah tersebut orang-orang yang benar-benar sesuai dengan kriteria yang berhak menerima zakat".

Melalui musyawarah tersebut, maka penyaluran zakat kepada yang berhak akan lebih mudah dan lebih tepat karena melibatkan berbagai pihak yang mengetahui keadaan di lapangan. Sehingga keputusan yang disepakati dalam musyawarah tersebut dijadikan sebagai acuan bagi BMK untuk mendistribusikan dan mendayagunakan dana zakat dengan harapan agar tepat pada sasarannya. 


\section{Prinsip efisiensi}

Sebagaimana dalam aturan, biaya-biaya administrasi atau operasional dalam pelaksanaan pengelolaan zakat pada BMK telah dibebankan dari anggaran daerah (APBK-Anggaran Pendapatan dan Belanja Kabupaten $)^{48}$ melalui sekretariat BMK. Untuk hak asnaf amil, BMK tetap mengalokasikan dana amil yang bersumber dari zakat. Hak para amil (berupa insentif atau honor) masih tetap dibebankan dari dana zakat, baik untuk amil dalam lingkungan BMK (pelaksana dan sekretariat) maupun untuk amil di luar BMK yang secara langsung terkait dengan pelaksanaan zakat pada BMK yakni dari dari unsur Kampung, dari unsur Dusun, serta dari unsur Kecamatan (selaku pengawas Baitul Mal Kampung). Alokasi untuk amil yang ditentukan oleh BMK sebagaimana pada Tabel 3 yakni sebesar 15\% dari dana zakat. Akan tetapi realisasinya dalam beberapa tahun terakhir menunjukan persentase di bawah $15 \%$, dan hanya melebihi sedikit dari ketentuan maksimum seperdelapan bagian (12,5\%). Realisasi penggunaan dana amil pada tahun 2015 dan 2016 masing-masing sebesar 13,84\% dan 13,83\%. Namun demikian, jika mengacu pada besaran maksimum yang telah ditentukan maka penggunaan dana amil pada BMK belum memenuhi kategori efisien. Karena, besaran dana amil masih melebihi ketentuan secara syariah dan di sisi lain biaya-biaya administrasi atau operasional BMK juga telah ditunjang oleh anggaran daerah. Sehingga seyogianya penggunaan dana amil menjadi lebih efisien karena biaya administrasi atau operasional telah didukung oleh anggaran daerah. Jika diprediksikan masih terjadi kekurangan dalam pemenuhan hak amil, mungkin dapat dilakukan penyesuaian dalam penyusunan rencana kebutuhan anggaran dari daerah.

\section{Simpulan}

Simpulan yang diperoleh mengenai prinsip-prinsip good governance perspektif Qardhawi dalam pengelolaan zakat pada Baitul Mal Kabupaten (BMK) Aceh Tengah adalah sebagai berikut: Prinsip syariah telah sesuai dengan Al-Quran dan Hadis, serta mengikuti perkembangan fiqih zakat. Pengelolaan dana zakat merujuk pada aturan positif yang secara substantif berlandaskan pada hukum syariah. Prinsip amanah dijalankan sebagaimana pada QS At-Taubah:60. Meskipun sebagai PAD, zakat tidak dicampur dengan penerimaan lain. Prinsip keadilan dilakukan melalui pendistribusian ke wilayah (Kampung) di mana zakat diperoleh dan ditambah pembagian zakat dari Kabupaten dengan menyesuaikan keadaan/ banyaknya mustahiq. Zakat dialokasikan untuk seluruh asnaf (kecuali riqab), dan

48 Pasal 43 ayat (2) pada Qanun Aceh No. 10 Tabun 2007 tentang Baitul Mal 
persentase terbesar untuk fakir miskin. Prinsip akuntabilitas diwujudkan melalui laporan dan ditujukan kepada pemerintah serta masyarakat. Namun, laporan dibuat belum melalui sistem akuntansi zakat yang memadai. Prinsip transparansi dilaksanakan dengan aktif mempublikasikan informasi perkembangan dana zakat serta program-program melalui berbagai media. Namun belum menggunakan media akses informasi yang lebih luas dan lebih fleksibel untuk saat ini. Prinsip profesionalitas dalam mendukung pelaksanaan zakat belum diimplementasikan, di mana tidak adanya standarisasi kompetensi amil yang relevan dengan zakat pada saat proses rekruitmen. Prinsip partisipasi telah berjalan dengan melibatkan pihak-pihak dari unsur Kampung dan Dusun melalui musyawarah di antara mereka. Serta pada prinsip efisiensi, masih belum memperhatikan batas maksimum dana amil yang sesuai ketentuan syariah.

Dari hasil pembahasan, prinsip-prinsip good governance pada pengelolaan zakat ditinjau dari beberapa prinsip yang secara tidak langsung tersirat dalam pandangan Qardhawi secara umum telah dilaksanakan dengan baik di Baitul Mal Kabupaten Aceh Tengah. Prinsip-prinsip tersebut adalah prinsip amanah, keadilan, dan partisipasi. Dan terdapat beberapa prinsip yang perlu untuk diupayakan peningkatannya yakni prinsip akuntabilitas, transparansi, efisiensi, dan profesionalitas. Serta untuk tetap menjaga prinsip syariah, agar pemangku kebijakan (regulator) meninjau kembali menyangkut mekanisme zakat sebagai PAD. Agar meminimalkan peluang kemungkinan terjadinya keterlambatan pencairan, sehingga likuiditas dana zakat lebih diutamakan. Karena secara syariah, dana zakat yang telah ada harus siap dan bisa segera untuk dipergunakan.

\section{Daftar Pustaka}

Abdullah, Mal An. Corporate Governance Perbankan Syariah di Indonesia. Yogyakarta: Ar-Ruzz Media, 2010

Ali, Mohammad Daud. Sistem Ekonomi Islam: Zakat dan Wakaf. Jakarta: UI-Press, 1988.

Atabik, Ahmad. Manajemen Pengelolaan Zakat Yang Efektif Di Era Kontemporer. ZISWAF. Vol. 2, No. 1: 2015.

Endahwati, Yosi Dian. Akuntabilitas Pengelolaan Zakat, Infaq, dan Shadaqah (ZIS).JINAH. Vol. 4, No. 1: 2014.

Fadli, Ahmad. Good Governance Zakat Di Indonesia. Al-Iqtishadi. Vol. 2 No. 1: 2015. 
Gamal, Merza. Aktifitas Ekonomi Syariah (Catatan Dakwah Seorang Praktisi Perbankan Syariah). Pekanbaru: Unri Press, 2004.

Hafidhuddin, Didin. Panduan Praktis tentang ZIS. Jakarta: Gema Insani Press, 1998

Haq, M. Khafidh A.B. \& Djayusman, Royyan R. Analisis Efisiensi Lembaga Amil Zakat terhadap Pengentasan Kemiskinan (Studi Kasus di LAZ USP 20082013). Islamic Economics Journal. Vol. 1, No. 2: 2015.

Haryanto \& Sahmuddin \& Arifuddin. Akuntansi Sektor Publik, Edisi Pertama. Semarang: Badan Penerbit UNDIP, 2007.

Jasafat. Manajemen Pengelolaan Zakat, Infaq Dan Sadaqah Pada Baitul Mal Aceh Besar.Jurnal Al-Ijtimaiyyah. Vol. 1, No. 1: 2015.

Jumaizi \& Wijaya, Zainal A. Good Governance Badan Amil Zakat, Infak dan Sedekah Dan Dampaknya Terhadap Keputusan dan Loyalitas Muzaki. Majalab Ilmiah Informatika. Vol. 2 No. 3: 2011.

Kadry, R. Analisis efisiensi lembaga amil zakat (LAZ) di Indonesia. (Studi Kasus Pada Rumah Zakat, LAZIS Swa-daya Ummah, Dompet Dhuafa dan YBUI BNI Tahun 2010-2012). Tesis tidak diterbitkan. Yogyakarta: UIN Sunan Kalijaga, 2014.

Kementerian Agama RI. Pedoman Pengawasan Lembaga Pengelola Zakat. Dirjen Bimbingan Masyarakat Islam-Direktorat Pemberdayaan Zakat, 2012.

Kuncaraningsih, H \& Ridla, M. Rasyid. Good Corporate Governance dalam Meningkatkan Kepuasan Muzakki di Baznas. Jurnal MD. Edisi Januari-Juni, 2015.

LAN. Sosialisasi Sistem Akuntabilitas Kinerja Instansi Pemerintah (AKIP), modul 1 "Akuntabilitas dan Good Governance". Jakarta: Cet.1 - Maret, 2000.

Lestari, Puji \& Pratiwi, Umi, \& Ulfah, Permata. Identifikasi Faktor Organisasional dalam Pengembangan "E-Governance" pada Organisasi Pengelola Zakat. MIMBAR. Vol. 31, No. 1: 2015.

Moleong, Lexy J. Metodologi Penelitian Kualitatif. Cetakan 29. Bandung: Remaja Rosdakarya, 2011.

Muhammad \& Abubakar. Manajemen Organisasi Zakat: PerspektifPemberdayaan 
Umat dan Pengembangan Organisasi Pengelola Zakat. Malang: Madani, 2011

Mursal. Profesionalisme Badan Amil Zakat Daerah (BAZDA) Kabupaten kerinci. Al-Qishthu. Vol, 14, No.1: 2016.

Nikmatuniayah \& Marliyati. Akuntabilitas Laporan Keuangan Lembaga Amil Zakat di Kota Semarang. MIMBAR. Vol. 31, No. 2: 2015.

OECD. OECD Principles of Corporate Governance. Paris: OECD Publications Service, 2004.

Qanun Aceh No. 10 Tabun 2007 tentang Baitul Mal.

Qardhawi, Yusuf. Hukum Zakat. Terjemahan oleh Salman Harun, Didin

Hafidhuddin, dan Hasanuddin. Bogor: Pustaka Litera Antar Nusa, 2002.

Qardhawi, Yusuf. Spektrum Zakat dalam Membangun Ekonomi Kerakyatan.

Terjemahan oleh Sari Narulita. Jakarta: Zikrul Hakim, 2005.

Sedarmayanti. Good Governance "Kepemerintahan Yang Baik" Bagian Kedua:

Membangun Sistem Manajemen Kinerja Guna Meningkatkan Produktifitas.

Bandung: Mandar Maju., 2004.

Setiadi, M. Romi \& Hambali, Yoyo. Peran Amil Zakat dalam Mengoptimalkan Zakat Produktif: Studi Analisis Badan Amil Zakat Daerah (BAZDA) Kota Bekasi. Maslahah. Vol. 7, No. 1: 2016.

Setianingrum, Any. Desentralisasi Fiskal Kontemporer dalam Perspektif Kebijakan Publik Islam. Ekonomika-Bisnis. Vol. 4 No.1: 2013.

Suharto, Ugi. Zakat sebagai Lembaga Keuangan Publik Khusus: Refleksi Kitab Al Amwal Karya Abu Ubaid. Zakat \& Empowering-Jurnal Pemikiran dan Gagasan. Vol. 2: 2009

Triyuwono, Iwan. Sinergi Oposisi Biner: Formulasi Tujuan Dasar Laporan

Keuangan Akuntansi Syari'ah. IQTIS AD Journal of Islamic Economics. Vol. 4, No. 1:2003.

Undang-Undang Republik Indonesia Nomor 11 Tahun 2006 tentang Pemerintahan Aceh

Undang-Undang Republik Indonesia Nomor 18 Tabun 2001 tentang Otonomi 
Khusus bagi Provinsi Daerah Istimewa Aceh sebagai Provinsi Nanggroe Aceh Darussalam.

UNDP. Governance For Sustainable Human Development. A UNDP Policy Document, 1997.

Utamy, Hebby Rahmatul. Keadilan Ekonomi dalam Pendistribusian Zakat oleh Baznas Kabupaten Tanah Datar. Jurnal Tamwil. Vol. I, No. 2: 2015.

Yin, Robert K. Studi Kasus: Desain dan Metode. Cetakan 14. Jakarta: Rajawali Pers, 2002. 